\title{
REVISITING POPULAR BENGALI FOLKLORES TO RE-IMAGINE THE PAST AND ENGAGE WITH THE PRESENT: GUN ISLAND AND THE TRIBULATIONS OF CLIMATE CHANGE
}

\begin{abstract}
Amitav Ghosh, in his 2019 novel Gun Island chooses to discourse on the antipathetic relation of human progress and the environment manifested as climate change. In this remarkable novel Ghosh visits two popular Bengali folklores: Manasa Devi - a snake goddess, and Chand Sawdagor - a merchant who was cursed by the snake goddess, and utilizes the stories to re-imagine a past in which certain events take place that eerily parallels the present, especially the issue of climate change. Ghosh's appropriation of ideas from the epic Manasa Mangal Kabyo - from the canon of Bengali folklore - and shaping them to include pressing contemporary climate issues that oppress individuals, environs, animal habitats, and global major cities around the world, invest the thesis of the novel with global significance. Ghosh transmutes the folklores by reimagining the past, so they come to inform a global scene: dictating and vindicating outcomes all over the world. Ghosh concludes that absence of a globally accepted authority that would negotiate the human-environment interaction for the betterment of both is a dangerous gap.
\end{abstract}

Keywords: climate change; progress; migration; global warming; snake goddess; myth.

Amitav Ghosh is renowned for making novels out of colonial histories and its complexities. In his novels he had unraveled a troubled world of the past which was also international in scope, containing characters of various religious denominations, nationalities and races (Sowmiyalatha and Kalaiarasan 360). In his novels Ghosh also portrays the migrants, the marginalized and the refugees, and gives them a voice which is uttered against the forces that oppress, disenfranchise and sideline them from the dominant historical narratives of the time (Roselin and Nirmala 109). Ghosh's 2019 novel Gun Island offers the reader

\footnotetext{
* School of Humanities and Social Sciences at Brac University, Dhaka; Bangladesh.
} 
University of Bucharest Review $\propto$ Vol. XI/2021, no. 1 (new series)

Re-writing, Re-imagining the Past(III)

the trade mark Ghosh protagonists representing different nationalities, religions and social stations (which include the marginalized, the refugee, and the subaltern). But it also includes as the central character, or narrator of the novel, a global citizen, and his relations with other globetrotting figures of importance who play vital roles in the story that Ghosh tells us. For Gun Island also unfolds a troubled world which is international in scope, has complexities and a relation with the past. But it is mainly a forward looking novel cognizant of the present, and dwells in the tribulations of the present world that its characters inhabit in. The novel does not have the colonial setting, and the recurring historic period of nineteenth century - that are regular in Ghosh novels- when India was in the grip of the British rule, and its colonial masters determined the physical and geographic movement of its people. In a departure from his traditional trope Ghosh tackles the pressing issues of climate change, climate migration, and environmental degradation that plague not only his native Bangladesh, and India, but also major metropolises in very developed nations such as Italy and USA. His virtuoso storytelling is shown in high relief against the mythological stories of Manasa Devi and Chand Sawdagor - which are starting points for the novel that is Gun Island. As the mystery thickens, Ghosh's protagonist Dr. Deen Datta, a rare book dealer from Brooklyn, New York, is persuaded to recall the ancient story of The Merchant and Manasa Devi, a folklore still surviving in the eastern India and Bangladesh, in many versions and guises, that mainly talks about the vengeance of a snake goddess, and the running away of a merchant from her wrath. But through this forgotten tale Ghosh opens up the portals of new stories that are in the making and are affecting us in the most urgent manner (McDowell 175). After a chance encounter, and casual banter with his distant relative Kanai Dutt concerning Bengali folklore, Dinu (Deen Datta, the narrator, is called so in Gun Merchant) re-encounters the mythical merchant character called Chand Sadagar during his annual visit to Kolkata, and is forced to consider the ancient story of Chand Sadagar fleeing overseas to escape the vengeance of Manasa Devi, the snake goddess. As the story progresses we are brought to consider the pressing issues of rising sea levels that is making the coastal areas of Bangladesh uninhabitable for humans and animals alike, human trafficking and migration, endangered animals, and global warming that is having a negative impact also on the urban centres of developed nations exemplified in the situations of cities such as Italy's Venice, and USA's Los Angeles.

\section{Climate Change and Climate Refugees}


In the beginning of the story, under the wrapping of storytelling Ghosh starts his discourse on climate change by citing the November 1970 cyclone of Bangladesh which was responsible for almost half a million lives. That cyclones, tidal waves and flukes of nature held hostage the lives of millions living in the coastal areas of Bangladesh and India, for whom such conditions were a given fact of life is recognized early on in Gun Island:

Eight days earlier - on November 12, 1970, to be precise - a Category 4 cyclone had torn through the Bengal delta, hitting both the Indian province of West Bengal and the state that was then called East Pakistan (a year later it would become a new nation, Bangladesh). Storms had no names in this region back then but the 1970 cyclone would come to be known as the Bhola cyclone. In terms of casualties the Bhola cyclone was the greatest natural disaster of the twentieth century; its toll conservatively estimated at three hundred thousand lives lost but the actual number may have been as high as half a million. (Ghosh 13)

In the story, Nilima, Ghosh's interlocutor, furnishes Ghosh with an interesting anecdote coming from the November 1970 cyclone. She tells him that despite the powerful surge of the cyclone which left in its wake death, carnage and devastation, she witnessed some survivors, in a village in the Sundarbans, who were unharmed by the cyclone. Back then, these survivors attributed their good fortune to the protection of the mythical Manasa Devi and their having been sheltered in her shrine (in the Sundarbans) while the cyclone was blowing:

She learnt that no one from that hamlet had suffered any bodily harm; they had even managed to salvage their belongings and stocks of food.

To what did the village owe its good fortune?

The answer startled Nilima: her informants told her that the miracle was due to Manasa Devi, the goddess of snakes, who, they said, was the protector of a nearby shrine.

Shortly before the storm's arrival, as the skies were turning dark, the shrine's bell had begun to ring. The villagers had rushed there, taking whatever food and belongings they could carry. Not only the shrine's walls and roofs kept them safe from the storm, it had continued to shelter them afterwards, even providing them with clean, fresh water from its well- a 
rare amenity in Sundarbans. (Ghosh 14)

In the above what is interesting is that obedience, allegiance and devotion to Manasa Devi can actually protect lives, and negate the adverse effects of nature's rage. On the other hand, she is reputed to be violent and angry if disobeyed, and this rage is manifested in snake bites and other curses as depicted in the medieval Manasa-mangal Kavyas (Jash 170). It is precisely this disobedience to her on which the story of the apocryphal Gun Merchant stands in Gun Merchant. In Manasa-mangal Kavyas the merchant who angered Manasa Devi is called Chand Sadagar. Chand Sadagar, the hero of the Manasa-mangal Kavyas was a wealthy merchant who accumulated wealth through sea-borne trade, and owned large fleets of trading vessels which carried commodities to overseas markets (Chaudhury 304).

In various versions of the poem that are in essence Manasa-mangal Kavyas, there are accounts of the voyages to the sea. One such account:

The poet then gives a detailed account of the route to the sea through the river Bhagirathi. According to Bipradas' Manasa-mangal Kavyas Chand Sadagar passed through Hughli, Bhatpara, Kankinara, Bhadreswar, Ichapur, Bankibazar, Khardah, Rishra, Sukhchar, Ariadaha, Chitpur, then by passing Kalikata to Kalighat, Kumarhati, Baruipur and finally at the river mouth meeting the sea. Thereafter the poet describes the perils faced by the Sadagar at the open sea. It seems that the main problem was sighting of the shore and sailing for miles in the open sea.

So far so good. But the big question here is how far the above can be reconciled with historical reality. So far as the route from the Sadagar's home to the sea is concerned, there is little doubt that it was quite realistic and there is no room for any imaginative portrayal. But what about the main story line that the Sadagar went to Ceylon for trading with fourteen vessels. (Chaudhury 307)

In the actual Manasa-mangal Kavyas the noncompliant Sadagar flees to Ceylon (present day Sri Lanka) to protect himself from the wrath of the Manasa Devi. According to Sushil Chaudhury there is a certain realism in the poem as the said vessels of the Sadagar sail through real geographic locations (309). Amitav Ghosh reimagines the events of the Manasa-mangal Kavyas by thrusting the Gun 
Merchant in the deep jungle of Sundarbans as the errant merchant who sacrilegiously behaved to provoke the wrath of the snake goddess- Manasa Devi, and made his escape via the sea route:

Like Chand, the Gun Merchant was said to have been a rich trader who had angered Manasa Devi by refusing to become her devotee. Plagued by snakes and pursued by droughts, famines, storms, and other calamities, he had fled overseas to escape the goddess's wrath, finally taking refuge in the land where there were no serpents, a place called 'Gun Island'-Bondukdwip. (Ghosh 16)

In appropriating the Manasa-mangal Kavyas Ghosh's leap of imagination also lends a certain realism to the escape of the Gun Merchant. As opposed to Chand Sadagar reaching Ceylon, the Gun Merchant - sometime in the fifteenth century, according to Ghosh and other historians who accede that this was the time when Manasa-mangal Kavyas was composed (Chaudhury 303), escapes to Venice by sea. The extreme urban European city in the middle of the sea, home to a network of merchants which included Jews, Greeks, Arabs, and a host of other foreigners, was the commercial centre of the world in the fifteenth century (Apellaniz 158). According to Ghosh "This, if any, was a place that would seem secure from non-human intrusion: apart from a few ornamental trees and plants there was almost nothing in sight that was not made by human hands. Here surely the Gun Merchant would have known himself to be beyond his tormentor's grasp" (152). But this banishment of the thick jungle with its snakes, and its deity, kept so far at bay across the seas in the deep recesses of the Sundarbans in the South East point of Bengal, does not provide the much sought respite and safety to the Gun Merchant. Ghosh does not provide any further description as to exact nature of the torment that might have reached the Gun Merchant in Venice, but offers us an alternative perspective that vindicates the existence of the Manasa Devi in the mythical realm of the Manasa-mangal Kavyas. Ghosh predicates her existence and worshipping of the Manasa Devi on a very real and urgent purpose: and that happens to be the protection of the natural environment, to keep it safe from the avarice and incursion of human habitat. In East Bengal and its adjoining regions (which include present day Bangladesh and part of West Bengal) the serpent deity, Manasa Devi, is being worshipped for centuries. The deity is still being worshipped, and during the month of July- 
August a special worship called Naga Panchami is enacted by Hindus. The anthropomorphic serpent goddess is represented via innumerable images of the deity, and stone idols, which are housed now in many of the museums of Bangladesh and India. The earliest of them dates back to eleventh century, and proves how the serpent goddess has found its way to the psyche of all sections of the Hindu society in that part of India and Bangladesh over the centuries (Jash 174). Ghosh, as much as he considers the myth and the story of the predicament of the Gun Merchant, also sees this realism of the worshipping of the Manasa Devi, and her (seemingly malignant) existence from the perspective of the goddess herself:

I wasn't looking at the Merchant's predicament from his own point of view but rather from the perspective of his pursuer, the goddess herself. And then the pursuit no longer seemed to be an almost incomprehensible vindictiveness but something more fraught, and even tender, a search driven by fear and desperation.

I remembered my readings of the Merchant legends of Bengal and how inapt the word 'goddess' had seemed to me in relation to the depiction of Manasa Devi in these epics. 'Goddess' conjures up an image of an allpowerful deity whose every command is obeyed by her subjects. But the Manasa Devi of the legend was by no means a 'goddess' in this sense; snakes were not so much her subjects as her constituents; to get them to do her bidding she had to plead, cajole, and persuade. She was in effect a negotiator, a translator- or better still a protavoce- as the Italians say, 'a voice-carrier' between two species that had no language in common and no shared means of communication. Without her meditation there could be no relationship between animal and human except hatred and aggression. (Ghosh 152)

From the above we see that what Ghosh is trying to establish is that Manasa Devi is trying to protect the nature- the deep jungle or forest (or broadly the ecology it may be assumed) -from the persistent incursion and abuse of human beings. Her wrath, and the legend of her command of the poisonous creatures of the jungle are in effect potential deterrents that must be negotiated with, and taken into account before humans venture into the jungle. Ad they think of usurping its essential properties and qualities, they must also think of the 
consequences of doing so. Retribution in some form, such as a snake-bite or suffering a tidal wave, cyclone, or flood will have to be endured by human beings when transgressions against nature is made. Manasa Devi, in effect is the custodian of the boundary that keeps the human world, and the world of the nature and animals separate. In the narrative of the Gun Merchant, Manasa Devi seeks out the transgressing merchant for retribution owing to this very purpose.

Hence the urgency of her search for the Merchant: for if he, and others like him, were to disavow her authority, all those unseen boundaries would vanish, and humans, driven- as was the Merchant, by the quest for profitwould recognize no restraint in relation to other living things. This was why the Merchant had to be found; this was shy his attempts at concealment had to be thwarted at all costs. (Ghosh 153)

In the novel when we return our gaze from the adventure of the Gun Merchant as he escapes to Venice to the present day death of dolphins in the Sundarbans region we are brought head to head to the issue of human avarice, and avarice induced invasions into the forest that causes such deaths. Dinu meets Piya, marine biologist, environmental activist, and researcher who works on the movements of the Sundarbans dolphins. Piya attributes many of the "beachings" or running aground to death of these dolphins to an oil refinery which was built in the upriver of the Sundarbans whose chemical effluence was causing the death of the endangered dolphins:

She pointed upriver, 'I have a feeling that the culprit here is a refinery that started up a couple of years ago- it's not far from here as the crow flies. We'd been fighting it for years- I mean the trust and an alliance of environmental groups- but we were up against some very powerful people, a giant conglomerate that's got politicians in its pocket on both sides of the border. (Ghosh 96)

In another scene of the novel when Dinu meets Rafi, a young Sundarbans inhabitant, who would soon migrate to Italy (via illegal sea routes, and by paying the human traffickers), he finds that the young lad is lamenting the ecological distress that the forest was already in: its resources no longer able to provide sustenance to its human inhabitants. The following conversation that unfolds 
between Dinu and Rafi is illustrative of the ecological plight that places like Sundarbans are caught in and the tremendous pressure to find alternative means of livelihood that are weighing down on its inhabitants:

'Some things. But there was much that he didn't want to teach me.'

'Like what?'

He shrugged. 'Things about animals, and fish, and the water- he' $\mathrm{d}$ tell me that I didn't need to learn what he knew because the rivers and the forest and the animals are no longer as they were. He used to say that things were changing so much, and so fast, that I wouldn't be able to get by here- he told me that one day I would have no choice but to leave.'

'And go where?'

He shrugged. 'I don't know. Wherever people go. Bombay, Delhi- I don't know.' (Ghosh 86)

In subsequent events of Gun Island, it so transpires that Rafi eventually pays illegal human traffickers to make his way to Italy, to Venice to be precise, where he expects to earn a better living. Eventually Rafi's Sundarbans friend Tipu- also follows him, and gets stranded in the high seas on a refugee ship which the Italian authorities are unwilling to accept. The refugee ship - only identified as the 'blue boat'- and the commotion surrounding the ship's admission to the water of Italy forms the denouement of the novel Gun Island. Ghosh, with virtuosity, depicts the international issue that is posed by the economic and climate migrants like Rafi and Tipu. Such refugee boats carrying thousands of migrants from South Asia and Middle East is a recent phenomenon of global urgency and challenge. According to a 2017 UNHCR report on sea borne migration in 2017 alone 119,400 refugees arrived in Italy illegally via sea (8). In 2016 the figure was even greater - 181,400 arrived via sea (8). Of course the scenes surrounding the refugee ship in Gun Island easily posits that many of these refugees were a direct victim climate change. The rising sea level, consequent flooding and global warming, has made places like Sundarbans bereft of any livelihood that young people of Rafi or Tipu's generation can thrive on. They must find precarious ways - impoverished and uneducated as they are- to migrate to countries that may supposedly provide them with a future. But they are unwelcome in these nations: 
An angry howl rose from the other ship as it drew level with us. The people on deck were near enough that we could see their faces clearly. They were mainly young men, many with their faces painted in the colours of their football clubs. Many appeared to be drunk.

When they began to shout slogans- 'Close borders now!L'Italia agli Italiani!' We joined hands and shouted back: 'NO to xenophobia! NO to hate!' (Ghosh 274)

The above quotation reveals to us the challenges and plights not only of the climate refugees or political refugees who embark on a death defying journey by sea, but also the political ideologies that are ranged against each other concerning these victims of world conflicts, or climate crisis. On the one hand we have the nationalist and populist forces that are bent on safeguarding their affluent societies and economies, and not at all interested to share their wealth with dispossessed foreigners. On the other hand, we also have globalists and international minded people like Dinu and Cinta who humanely consider the human consequences of climate change, and the impacts that must be absorbed by the world.

The eerie parallel between the fleeing of the Gun Merchant from the wrath of the Manasa Devi, and the fleeing of Rafi and Dinu from an ecologically decayed, hostile environment that the Sundarbans had become- is reminiscent of the consequences of the transgressions of human agents against the environment. Commercial greed and profit seeking, the prospects of material progress and improved living standards destroy the environment. Although no Manasa Devi is respected, or negotiated with, before contemporary politics and progress make its incursions into the jungles, the wrath and vengeance of Manasa Devi is still operant. It does not present itself as snake bites necessarily, but the rising sea level, extinction of animal habitats, plants, and hostile weather result in the same consequences. Like the Gun Merchant individuals like Rafi and Tipu are forced to flee their native countries, native places. By invoking a variation on the story of the Manasa-mangal Kavyas Ghosh shows us by means of an ancient legend that consequences of environmental transgressions have the same nature and are reflected in the adverse effects of climate change, and the utter plight of climate migrations.

\section{Climate Change and the Developed World}


The wildfire in California had become a regular yearly occurrence, and residents being told to leave their homes and neighborhood because of the progress of an all-consuming wildfire is widely reported in media (Chediak). In Gun Island Ghosh depicts the issue memorably, and possibly as an example of the detrimental effect that global warming or climate change can have even on cities of very developed nations such as the United States of America. The protagonist, Dinu, visits Los Angeles to attend a conference, and during his flight to Los Angeles he is a victim of strange dreams where he sees serpents and eagles: a reference again to the Manasa Mangal Kavyas legend that was still gripping him. However, when he actually arrives in Los Angeles, he is totally taken aback by the all-consuming wild fire that has stopped life in Los Angeles. The conference could barely take place:

But this was not the case when we arrived for the opening event of the conference: there were no shuttle buses anywhere in sight and, odder still, the car park, which usually filled up as soon as the museum opened its gates, was almost empty.

There was only a single security guard at the entrance and all she could tell us was that the museum was drastically shorthanded that morning; many of her colleagues had not been able to get to work because road closures caused by the still raging wild-fires. (Ghosh 120)

Similar predicaments are faced by Dinu when he and Cinta, his Italian friend, sojourn in Venice. Flood waters inundating Venetian streets are now a frequent occurrence. Dinu and Cinta become startled one evening by the waling of a siren that actually announce that flood water will be there in neighborhood (Ghosh 229). Dinu, experiences another strange encounter in Venice, which again reminds him of the Gun Merchant, and his escape to Venice, and that is a spider in his apartment. Normally such spiders are not supposed to be found in Venice, and for a while Dinu almost fears that he must have hallucinated this. Yet, the reality that is global warming and the rising sea level had not only brought frequent flooding to Venice, but also strange creatures to its shores. Troubled by the flooding, and the spider, when Dinu asks Cinta what she thinks of the contemporary world, and whether it was possessed by some menacing demon or not, here is what she replies: 
University of Bucharest Review $\propto$ Vol. XI/2021, no. 1 (new series)

Re-writing, Re-imagining the Past (III)

'That the world of today presents all symptoms of demonic possession.'

I gasped. 'What? You can't be serious, Cinta! In what sense does it present the symptoms of demonic possession?'

'Just look around you, caro.' There was a touch of weariness in her voice now. 'Everybody knows what must be done if the world is to continue to be a livable place, if our homes are not to be invaded by the sea, or by creatures like that spider. Everybody knows and yet we are powerless, even the most powerful among us. We go about our daily business through habit, as though we were in the grip of forces that have overwhelmed our will; we see shocking and monstrous things happening all around us and we avert our eyes; we surrender ourselves willingly to whatever it is that has us in its power.' (Ghosh 216)

Thus, we see that climate change is not only a developing country issue upsetting nations like Bangladesh and India, but also a negative force that upsets regularity of lives in urban centres of global renown such as Los Angeles, and Venice.

\section{Conclusion}

The story, revolving around the core of the legend of the Gun Merchant, rooted in the Manasa Mangal Kavya, with its associations of snakes, spiders, poisonous animals and supernatural wrath portends the climatic disasters that are to create havoc in all parts of the world, not only in nations which send boat loads of refugees, and cheap labor to the West, but the West itself. The present day dangers of climate change must be reckoned by the contemporary world; and being indifferent, or fleeing to another place like the Gun Merchant - to escape the rage of nature, are not viable solutions.

The ethics of climate change, and its human cost in the absence of any globally acceptable intermediary on the side of the inanimate environment and the animal world is what adds to its demonic nature, the precariousness of the situation. In Gun Island, Manasa Devi- the deity is a negotiator of sorts from the realm of myths who laid hold on the imagination and actions of the medieval Hindus of Bengal, regulated their actions and exploitations of the natural worldtheir forays into the jungle. Today, no such globally recognized deity is feared or revered; yet the consequences of transgression remain the same: climate refugees, loss of habitat, flooding and wild fires that we witness in Gun Island, are just a 
few of the proverbial 'snake bites' that plague the present world.

\section{Works Cited}

Apellániz, Francisco. "Venetian Trading Networks in the Medieval Mediterranean." The Journal of Interdisciplinary History, vol. 44, no. 2, 2013: 157-79.

Chediak, Mark. "California Wildfire Nears Lake Tahoe, Forcing Evacuations." Bloomberg.Com, Aug.2021. Ghosh, Amitav, and Amitav Ghosh. Gun Island. John Murray, 2020.

Jash, Pranabananda. "The Cult of Manasa in Bengal." Proceedings of the Indian History Congress, vol. 47, Indian History Congress, 1996: 169-77, http://www.jstor.org/stable/44141538.

MCDOWELL, ROBERT. “What Does One Call It?" Hudson Review, vol. 73, no. 1, Spring 2020: 168-75.

"Poetical Narratives and Historical Reality: A Study of the Bengali Literature, Fifteenth to Eighteenth Century." Trade, Politics, and Society: The Indian Milieu in the Early Modern Era, by Sushil Chaudhury, Routledge, Taylor \& Francis Group, 2017: 303-16.

Roselin, S.Gnana, and Nirmala Manuel. "History of the Deprived in the Select Novels of Amitav Ghosh." Language in India, vol. 18, no. 11, Nov. 2018: 105111.

Sowmiyalatha, R., and M. Kalaiarasan. "Colonial History in Amitav Ghosh's Sea Of Poppies." Language in India, vol. 18, no. 4, Apr. 2018: 358-61.

UNHCR. "Desperate Journeys - Refugees and Migrants Arriving in Europe and at Europe's Borders - January - December 2018." UNHCR, 30 Jan. 2019, www.unhcr.org/desperatejourneys/. 